\title{
Colonization of plants by human pathogenic bacteria in the course of organic vegetable production
}

\author{
Andreas Hofmann ${ }^{\dagger}$, Doreen Fischer ${ }^{\dagger}$, Anton Hartmann and Michael Schmid * \\ Department of Environmental Sciences, Research Unit Microbe-Plant Interactions, Helmholtz Zentrum München, German Research Center for \\ Environmental Health $(\mathrm{GmbH})$, Neuherberg, Germany
}

\author{
Edited by: \\ Nicola Holden, The James Hutton \\ Institute, UK \\ Reviewed by: \\ Eelco Franz, Centre for Infectious \\ Disease Control, Netherlands \\ Zhao Chen, Clemson University, \\ USA \\ *Correspondence: \\ Michael Schmid, Department of \\ Environmental Sciences, Research \\ Unit Microbe-Plant Interactions, \\ Helmholtz Zentrum München, \\ German Research Center for \\ Environmental Health ( $\mathrm{GmbH}$, \\ Ingolstaedter Landstrasse 1, \\ D-85764, Neuherberg, Germany \\ e-mail:michael.schmid@ \\ helmholtz-muenchen.de \\ ${ }^{\dagger}$ Present address: \\ Andreas Hofmann and Doreen \\ Fischer, Research Unit \\ Environmental Genomics, \\ Helmholtz Zentrum München, \\ German Research Center for \\ Environmental Health ( $\mathrm{GmbH}$ ) \\ Neuherberg, Germany
}

In recent years, increasing numbers of outbreaks caused by the consumption of vegetables contaminated with human pathogenic bacteria were reported. The application of organic fertilizers during vegetable production is one of the possible reasons for contamination with those pathogens. In this study laboratory experiments in axenic and soil systems following common practices in organic farming were conducted to identify the minimal dose needed for bacterial colonization of plants and to identify possible factors like bacterial species or serovariation, plant species or organic fertilizer types used, influencing the success of plant colonization by human pathogenic bacteria. Spinach and corn salad were chosen as model plants and were inoculated with different concentrations of Salmonella enterica sv. Weltevreden, Listeria monocytogenes sv. 4b and EGD-E sv. 1/2a either directly (axenic system) or via agricultural soil amended with spiked organic fertilizers (soil system). In addition to PCR- and culture-based detection methods, fluorescence in situ hybridization (FISH) was applied in order to localize bacteria on or in plant tissues. Our results demonstrate that shoots were colonized by the pathogenic bacteria at inoculation doses as low as $4 \times 10 \mathrm{CFU} / \mathrm{ml}$ in the axenic system or $4 \times 10^{5}$ CFU/g in the soil system. In addition, plant species dependent effects were observed. Spinach was colonized more often and at lower inoculation doses compared to corn salad. Differential colonization sites on roots, depending on the plant species could be detected using FISH-CLSM analysis. Furthermore, the transfer of pathogenic bacteria to plants via organic fertilizers was observed more often and at lower initial inoculation doses when fertilization was performed with inoculated slurry compared to inoculated manure. Finally, it could be shown that by introducing a simple washing step, the bacterial contamination was reduced in most cases or even was removed completely in some cases.

\section{Keywords: organic food, vegetable, organic fertilizer, Salmonella enterica, Listeria monocytogenes}

\section{INTRODUCTION}

The consumption of vegetables is essential for a healthy nutrition and is recommended by different health organization in order to provide minerals and vitamins as well as for the prevention of cardiovascular diseases (World Health Organization, 2003; United States Department of Agriculture, 2011). In the years 1997-1999 an increase of the consumption of fresh vegetables was recorded in the USA, staying on this high level for the following years (Blanck et al., 2008; Berger et al., 2010). Most of this food is consumed raw or after minimal processing. Therefore, it is crucial to avoid its contamination with human pathogenic bacteria, viruses or health threatening substances throughout the production chain. Nevertheless, in the last years an increasing number of outbreaks caused by the consumption of vegetables contaminated with human pathogenic bacteria were reported (Sivapalasingam et al., 2004; Heaton and Jones, 2008). For example, in 2007 lettuce was the one of the three most frequent sources of foodborne disease outbreaks in the USA (Center of Disease Control and Prevention, 2010).

Salmonella enterica and Listeria monocytogenes are two foodborne human pathogens involved in many outbreaks. In the years
2002-2007 S. enterica was the most frequent causative agent of foodborne diseases in the USA. The largest outbreak in this time period with 802 documented patients was traced back to the consumption of "hummus" (mashed chickpeas) contaminated with this bacterium (Center of Disease Control and Prevention, 2010). Hanning et al. (2009) summed up S. enterica outbreaks in the USA based on the consumption of fresh produce showing that many different vegetable plant species were involved in those outbreaks. Due to its importance as produce contaminant much research has been done in this direction proving the high potential of $S$. enterica to colonize surfaces as well as interior of various plants (Brandl, 2006; Berger et al., 2010; Krtinić et al., 2010). Listeria monocytogenes outbreaks based on the consumption of fresh produce were reported in lower numbers compared to those derived from other food sources (US Food and Drug Administration, 2003). Nevertheless, a recent outbreak of listeriosis in the USA in 2011 was caused by the consumption of contaminated cantaloupes (Center of Disease Control and Prevention, 2011). Also in sporadic cases of infections with L. monocytogenes, vegetables were identified as causative food source (Farber and Peterkin, 1991). However, in a high number of outbreaks or 
single cases, no specific food source could be identified, because of the very long incubation time until appearance of listeriosis symptoms (McLauchlin, 1996). Therefore, the US food and drug administration (FDA) as well as the EU dictate a zero tolerance policy for $S$. enterica and $L$. moncytogenes in ready to eat food throughout the production chain, although the EU-legislation allows $100 \mathrm{CFU}$ of L. moncytogenes in $25 \mathrm{~g}$ of sample material, for food already placed on the marked.

Various possibilities of contamination with human pathogenic bacteria exist within the vegetable production chain. For example, bacteria could be transferred to the plants by contaminated irrigation water, via soil or direct contact (Wachtel et al., 2002). Different wild animals were also proven to be possible carrier of various human pathogenic bacteria (Palmgren et al., 1997; Makino et al., 2000; Handeland et al., 2002; Millan et al., 2004; Renter et al., 2006; Hellström et al., 2008; Sánchez et al., 2010; Wacheck et al., 2010; Vieira-Pinto et al., 2011). It cannot be excluded that those animals can access the agricultural fields and directly contact the plants grown there. The fertilization with slurry or manure is an additional way of contamination (Chen and Jiang, 2014). It has been shown that organic fertilizers can contain various human pathogenic bacteria (Hutchison et al., 2004, 2005). A transfer via direct contact with the plants or indirectly via the fertilized soil is therefore possible. In order to enable a reduction of the pathogen load in the soil the US government dictates that organic fertilizer has to be incorporated not less than 120 days before harvest of plants. However, regulations regarding the time point of organic fertilizer application strongly differ between countries. Furthermore, contamination of produce may also occur in postharvest processing steps. For example L. monocytogenes was detected in samples of the food processing environment like door handles, floors and walls (O'Connor et al., 2010). Similar results for S. enterica were obtained in a comparable study (Lettini et al., 2012). Those bacteria can also form biofilms on stainless steel surfaces and by that be protected from disinfection (Sinde and Carballo, 2000).

Based on the hypothesis that most of the contaminations of vegetable plants by human pathogenic bacteria can effectively be reduced already at farm level, this study focuses on the first steps of the organic vegetable production chain at the farm level until harvest. In order to demonstrate the influence of plant host species and bacterial species on plant colonization success, the minimal bacterial infection doses of the selected bacterial strains S. enterica sv. Weltevreden, L. monocytogenes sv. $4 \mathrm{~b}$ and L. monocytogenes EGD-E sv.1/2a needed for the colonization of spinach or corn salad plants were determined in inoculation experiments. The S. enterica sv. Weltevreden strain used in this study was originally isolated from an outbreak of salmonellosis caused by the consumption of contaminated alfalfa sprouts (Emberland et al., 2007). The L. monocytogenes serotypes $1 / 2 \mathrm{a}$ and $4 \mathrm{~b}$ were selected because of their high clinical relevance as causative strains of a large number of listeriosis cases. To meet the zero tolerance policy in ready to eat foods throughout the production chain for the contamination with $L$. monocytogenes and S. enterica, another objective was to develop and apply a most sensitive and reliable combination of cultivation enrichment and PCR-detection approach for the studied pathogenic bacteria. Furthermore, the colonization sites of the inoculated bacterial species on plant roots were identified by combining fluorescence in situ hybridization (FISH) and confocal laser scanning microscopy (CLSM). The growth conditions in the axenic system as well as the absence of competition by soil bacteria might enhance bacterial colonization of plants (Klerks et al., 2007). Therefore, and in order to verify the results of the inoculation experiments, regarding the influence of plant- as well as bacterial species, in a more natural system, experiments in a soil system using spiked manure or slurry for fertilization of the plants were applied. By this, the influence of the type of organic fertilizer used, on plant colonization by the selected human pathogenic bacteria was analyzed. The results presented identified factors influencing the frequency of colonization of vegetable plants by human pathogenic bacteria. This may help to minimize the risk of produce contamination already at the farm level and thus may increase the safety for the consumer.

\section{MATERIALS AND METHODS PLANT SPECIES AND BACTERIAL STRAINS}

Spinach (Spinacia oleracea) variety "Butterflay" and corn salad (Vallerianella locusta) variety "Verte á ceour plein 2" (Bingenheimer Saatgut AG, Echzell-Bingenheim, Germany) and three bacterial strains were used for inoculation experiments: L. monocytogenes EGD-E sv. 1/2a (DSM20600, Deutsche Stammsammlung von Mikroorganismen und Zellkulturen GmbH, DSMZ, Germany), L. monocytogenes sv. 4b (SLCC4013, special Listeria culture collection, Würzburg, Germany) and S. enterica sv. Weltevreden (2007-60-3289-, culture collection, zoonosis laboratory, DTU-FOOD, Denmark).

\section{PREPARATION OF PLANT SEEDLINGS}

Plant seeds were surface sterilized according to the protocol published by Rothballer et al. (2003) with slight modifications. The seeds were washed in $1 \%$ Tween 80 ( $2 \mathrm{~min}$ ) and subsequent in $70 \%$ ethanol ( $2 \mathrm{~min}$ ) followed by three washing steps in sterile deionized water. After an incubation step in 13\% sodium hypochlorite solution (Sigma-Aldrich ${ }^{\circledR}$ Co., St. Louis, USA) (20 min) seeds were again washed three times in sterile deionized water, incubated in sterile deionized water for $4 \mathrm{~h}$ followed by a second incubation step in $13 \%$ sodium hypochlorite solution for $10 \mathrm{~min}$. Five washing steps in sterile deionized water completed the surface sterilization. Seeds were then placed on NB (Nutrient Broth) agar plates and incubated for 3 days at room temperature in the dark to allow germination and to control the success of surface sterilization. Only germinated seedling showing no visible contamination were used for further experiments.

\section{INOCULATION EXPERIMENTS IN AN AXENIC MODEL SYSTEM}

Listeria monocytogenes strains were cultivated in Brain-HeartInfusion (BHI) liquid media at $30^{\circ} \mathrm{C}$ and S. enterica sv. Weltevreden in buffered peptone water (BPW) at $37^{\circ} \mathrm{C}$ over night. The bacterial cells were washed and afterwards diluted in $1 \times$ PBS to a final density of $4 \times 10^{8} \mathrm{CFU} / \mathrm{ml}$. The germinated seedlings were inoculated for $1 \mathrm{~h}$ in different dilutions ranging from $4 \times 10$ to $4 \times 10^{6} \mathrm{CFU} / \mathrm{ml}$ of the different bacterial strains. Non-inoculated seedlings were used as control. After inoculation seedlings were planted to sterile "Phytatray 2"-boxes 
(Sigma-Aldrich ${ }^{\circledR}$ Co., St. Louis, USA) filled with $20 \mathrm{ml}$ sterile quartz sand and $10 \mathrm{ml}$ MS (Murashige and Skoog) medium (Sigma-Aldrich ${ }^{\circledR}$ Co., St. Louis, USA). Three boxes with four seedlings per box were prepared for each inoculation dose. Plants were grown for 3 weeks in a phytochamber (humidity: $50 \%$, day length: $14 \mathrm{~h}$, day temperature: $23^{\circ} \mathrm{C}$, night temperature: $18^{\circ} \mathrm{C}$, light intensity: $360 \mu \mathrm{mol} / \mathrm{m}^{2} \mathrm{~s}$ ) until harvest.

\section{SPIKING EXPERIMENTS IN THE SOIL SYSTEM}

Fresh, not processed organic bovine slurry and manure as well as organically managed agricultural soil (Ap horizon) obtained from the "Versuchsgut Scheyern" of the Helmholtz Zentrum München used in this study were initially tested for the presence of L. monocytogenes and S. enterica using enrichment as well as PCR-methods. Only organic fertilizer and soil considered free of those bacteria were used for further experiments. Bacterial strains were prepared as decribed above and added to slurry and manure at concentrations of $4 \times 10^{5}, 4 \times 10^{6}, 4 \times 10^{7}$, and $4 \times 10^{8} \mathrm{CFU} / \mathrm{ml}$ slurry or CFU/mg manure. Five hundred grams of fresh weight of agricultural soil were mixed with $100 \mathrm{ml}$ deionized water and $20 \mathrm{~g}$ of spiked manure or $30 \mathrm{ml}$ of spiked slurry and filled into planting pots. The amount of organic fertilizer used is in accordance to usual farming practice $\left(2-4 \mathrm{~kg} / \mathrm{m}^{2}\right.$ for manure, $3-61 / \mathrm{m}^{2}$ for slurry). The final bacterial concentrations in the soil were $2.4 \times 10^{4}, 2.4 \times 10^{5}, 2.4 \times 10^{6}$, and $2.4 \times 10^{7} \mathrm{CFU} / \mathrm{g}$ for slurry setups and $1.6 \times 10^{4}, 1.6 \times 10^{5}, 1.6 \times 10^{6}$, and $1.6 \times 10^{7}$ $\mathrm{CFU} / \mathrm{g}$ for manure. After a preincubation of the pots for 3 days at room temperature in a mini greenhouse (Edm. Romberg \& Sohn $\mathrm{GmbH} \&$ Co. KG, Ellerau, Germany), the sterile seedlings were planted in the pots. Three pots with four seedlings each were used per dilution step and incubated for 4 weeks in a phytochamber with the settings described above. Pots prepared with non-spiked organic fertilizer served as negative control.

\section{SAMPLING AND SAMPLE PREPARATION}

Plant samples of the axenic system were taken in triplicates whereas five samples per treatment were taken from the soil system. After harvest, root and shoot of the plants were separated aseptically. The plant parts were washed in $30 \mathrm{ml}$ of $1 \times$ PBS and afterwards ground in $1 \mathrm{ml} 1 \times$ PBS. One milliliter of the resulting cell suspension was used for enrichment cultures. Also the $1 \times$ PBS used for washing was further processed. After a cell harvest for $10 \mathrm{~min}$ at $6000 \mathrm{rpm}$ the resulting pellet was resuspended in $2 \mathrm{ml}$ of $1 \times$ PBS. Again $1 \mathrm{ml}$ of the cell suspension was used for further enrichment. Additionally, fixed samples of plant parts were prepared after cutting off parts of roots and shoots. Salmonella enterica inoculated or spiked samples were fixed in 4\% paraformaldehyde (PFA) according to Amann et al. (1990), whereas L. monocytogenes inoculated or spiked samples were fixed in 1:1 Ethanol/PBS (Roller et al., 1994). Fixed plant samples were stored at $-20^{\circ} \mathrm{C}$ in $1: 1$ Ethanol/PBS until further processing.

\section{ENRICHMENT OF THE BACTERIA}

For the selective enrichment of Listeria spp. $1 \mathrm{ml}$ of cell suspension was added to $9 \mathrm{ml}$ Buffered-Listeria-Enrichment-Broth (BLEB) (Merck KGaA, Darmstadt, Germany). After $2 \mathrm{~h}$ of preincubation at $30^{\circ} \mathrm{C}$ Listeria-Selective-Enrichment supplement (Merck KGaA, Darmstadt, Germany) was added and the culture was further incubated at $30^{\circ} \mathrm{C}$. After $24 \mathrm{~h}, 48 \mathrm{~h}$, and 7 days $0.1 \mathrm{ml}$ of the enrichment culture were transferred to $10 \mathrm{ml}$ Half-Fraser-Bouillon (Merck KGaA, Darmstadt, Germany) and incubated aerobically at $37^{\circ} \mathrm{C}$. Enrichment culture dependent detection of Listeria spp. was conducted after 24 and $48 \mathrm{~h}$ using Oxford-Agarplates (Merck KGaA, Darmstadt, Germany) and Palcam-Agarplates (Merck KGaA, Darmstadt, Germany) inoculated with the second enrichment culture. In case of a detection of Listeria spp. Rapid'L.mono medium (Bio-Rad Laboratories $\mathrm{GmbH}$, Munich, Germany) plates were used to identify L. monocytogenes. After inoculation, the identification plates were incubated at $37^{\circ} \mathrm{C}$ for $48 \mathrm{~h}$.

In order to enrich $S$. enterica cells, $1 \mathrm{ml}$ of cell suspension was added to $9 \mathrm{ml}$ of BPW and incubated aerobically $37^{\circ} \mathrm{C}$ for $24 \mathrm{~h}$. Afterwards cultures were streaked out on Xylose-LysineDeoxycholat (XLD) agar plates (Fluka, Buchs, Switzerland) and incubated at $37^{\circ} \mathrm{C}$ for $24 \mathrm{~h}$ in order to identify Salmonella spp.

\section{DNA-EXTRACTION}

DNA-extraction was conducted for L. monocytogenes after $48 \mathrm{~h}$ of enrichment in BLEB and for S. enterica after $24 \mathrm{~h}$ of enrichment in BPW. Cells of $2 \mathrm{ml}$ enrichment culture were harvested at $6000 \mathrm{rpm}$ for $10 \mathrm{~min}$. Salmonella enterica samples were processed directly whereas the pellet L. monocytogenes enrichment cultures was resuspended in $50 \mu \mathrm{l}$ of $300 \mathrm{U} / \mathrm{ml}$ Mutanolysin (Sigma-Aldrich ${ }^{\circledR}$ Co., St. Louis, USA) and incubated for $30 \mathrm{~min}$ at $37^{\circ} \mathrm{C}$ in order to increase the DNA-yield (Fliss et al., 1991). DNAextraction was conducted using the "Bio 101 FastDNA ${ }^{\circledR}$ SPIN Kit for Soil" and the "Fast-Prep-Instrument" (MP-Biomedicals LLC., Solon, USA) following the manufacturers' instructions. Quality and quantity of the extracted DNA was analyzed using a ND1000 Nanodrop-photometer (Thermo Fisher Scientific, Waltham, USA) and stored at $-20^{\circ} \mathrm{C}$ until further processing.

\section{PCR-BASED DETECTION OF L. MONOCYTOGENES AND S. ENTERICA}

The specific PCR-detection of L. monocytogenes was conducted using the iap targeted primerset MonoA/MonoB described by Bubert et al. (1992) and the detection of S. enterica by using the inv-A specific Primerset inv-Af/inv-Ar described by Rahn et al. (1992). The "Top Taq Polymerase" system (QIAGEN, Hilden, Germany) was applied for all PCR reactions following the manufacturers protocols. In order to increase specificity a "Touchdown-PCR" program (Don et al., 1991) was used. Therefore, the annealing temperature was lowered by $1^{\circ} \mathrm{C}$ every cycle starting from $70^{\circ} \mathrm{C}$ down to $63^{\circ} \mathrm{C}$ followed by 35 cycles with $63^{\circ} \mathrm{C}$ annealing temperature. The initial denaturation of $94^{\circ} \mathrm{C}$ for 5 min was followed by cycles comprised of a denaturation of $94^{\circ} \mathrm{C}$ for $30 \mathrm{~s}$, an annealing for $30 \mathrm{~s}$ and an elongation of $72^{\circ} \mathrm{C}$ for $1 \mathrm{~min}$. A final elongation step at $72^{\circ} \mathrm{C}$ for $10 \mathrm{~min}$ was integrated before samples were stored at $4^{\circ} \mathrm{C}$. Success of the PCR-reaction and length of the amplification product was controlled by applying horizontal gelelctrophoresis. To verify the correct amplification of a positive PCR-signal the resulting fragments were purified using the NucleoSpin ${ }^{\circledR}$ Extract II Kit (Macherey \& Nagel, Düren, Deutschland) and sequenced with a capillary sequencer ABI 3730 
(Applied Biosystems) following the chain termination method (Sanger et al., 1977).

\section{FLUORESCENCE IN SITU HYBRIDIZATION (FISH) AND CONFOCAL LASER SCANNING MICROSCOPY (CLSM)}

FISH was conducted on root samples of plants grown in the axenic system, initially inoculated with $4 \times 10^{6} \mathrm{CFU} / \mathrm{ml}$ of the respective bacteria. Since the plants were free of contamination, no species specific detection for L. monocytogenes or S. enterica was necessary and the application of bacteria-specific 16S-rRNA targeted EUB-338 probe mix (EUB-338 I Amann et al., 1990, EUB-338 II, and EUB-338 III Daims et al., 1999) was sufficient. FISH was conducted based on Manz et al. (1992) and Amann et al. (1992) with modifications. Hybridization was performed in a $2 \mathrm{ml}$ tube as described by Grube et al. (2009). After dehydration in an ethanol-series of 50,80 , and $100 \%$ ethanol for $3 \mathrm{~min}$ each, $100 \mu$ l of hybridization buffer [ $360 \mu \mathrm{l}$ of $5 \mathrm{M} \mathrm{NaCl}, 40 \mu$ l of $1 \mathrm{M}$ Tris/ $\mathrm{HCl}$ pH 8.0, $2 \mu \mathrm{l}$ of $10 \%(\mathrm{~m} / \mathrm{v})$ SDS, $1.6 \mathrm{ml}$ of deionized sterile water] as well as $10 \mu \mathrm{l}$ of a $20 \mathrm{ng} / \mu \mathrm{l}$ probe solution was added to the fixed sample. The hybridization at $46^{\circ} \mathrm{C}$ for $2 \mathrm{~h}$ was followed by a stringent washing step for $15 \mathrm{~min}$ at $48^{\circ} \mathrm{C}$ in washing buffer [ $9 \mathrm{ml}$ of $5 \mathrm{M} \mathrm{NaCl}, 1 \mathrm{ml}$ of $1 \mathrm{M}$ Tris/ $\mathrm{HCl} \mathrm{pH} 8.0$, $50 \mu \mathrm{l}$ of $10 \%(\mathrm{~m} / \mathrm{v}) \mathrm{SDS}$, add $50 \mathrm{ml}$ with sterile deionized water]. Afterwards, samples were placed on a microscope slide, embedded in Citifluor-A F1 (Citifluor Ltd., London, Großbritannien) and covered with a cover slid. CLSM analysis was performed using a LSM 510.meta (ZEISS, Oberkochen, Germany) equipped with a C-Apochromat ${ }^{\circledR} 63 \mathrm{x} / 1.2 \mathrm{~W}$ Korr. objective. The "Zeiss LSM Image Browser version 4.2” software was used for image processing.

\section{RESULTS \\ INOCULATION EXPERIMENTS IN THE AXENIC SYSTEM PCR and enrichment based detection of plant colonization}

The detection of the inoculated bacteria was based on selective enrichment and specific PCR. In all samples qualified as "positive" the inoculated bacteria were detected with at least one of the applied methods. The results are summarized in Table $\mathbf{1 .}$

In spinach and corn salad, S. enterica sv. Weltevreden was detected in all root samples and all samples of the root washing liquid. In spinach shoot and shoot washing liquid samples the bacteria also were found at initial inoculation doses as low as $4 \times 10 \mathrm{CFU} / \mathrm{ml}$. Nevertheless, in samples inoculated with $4 \times 10$ and $4 \times 10^{2} \mathrm{CFU} / \mathrm{ml}, S$. enterica sv. Weltevreden was detected more often in shoot plant samples compared to washing liquid samples. In contrast, corn salad shoots and the according washing liquids were found to be positive for the bacteria at inoculation doses of $4 \times 10^{3}$ and $4 \times 10^{2} \mathrm{CFU} / \mathrm{ml}$, respectively.

In spinach plants, both of the used L. monocytogenes strains were found in root and root washing liquid samples at all inoculation doses. In samples inoculated with L. monocytogenes sv. $4 \mathrm{~b}$ the lowest inoculation dose which resulted in a contamination of spinach shoot but not the according washing liquid could be observed was $4 \times 10^{2} \mathrm{CFU} / \mathrm{ml}$. Positive detection was possible in nearly all shoot and shoot washing liquid samples inoculated with higher bacterial doses. This was also found for L. monocytogenes EGD-E sv. $1 / 2 \mathrm{a}$ in samples inoculated with $4 \times 10^{2}$ $\mathrm{CFU} / \mathrm{ml}$ or more. In corn salad plants inoculated with L. monocytogenes sv. $4 \mathrm{~b}$ only few root and root washing liquid samples were positive at inoculation doses of less than $4 \times 10^{3} \mathrm{CFU} / \mathrm{ml}$ and only few shoots were colonized at inoculation doses below

Table 1 | Results of the inoculation experiment in the axenic system.

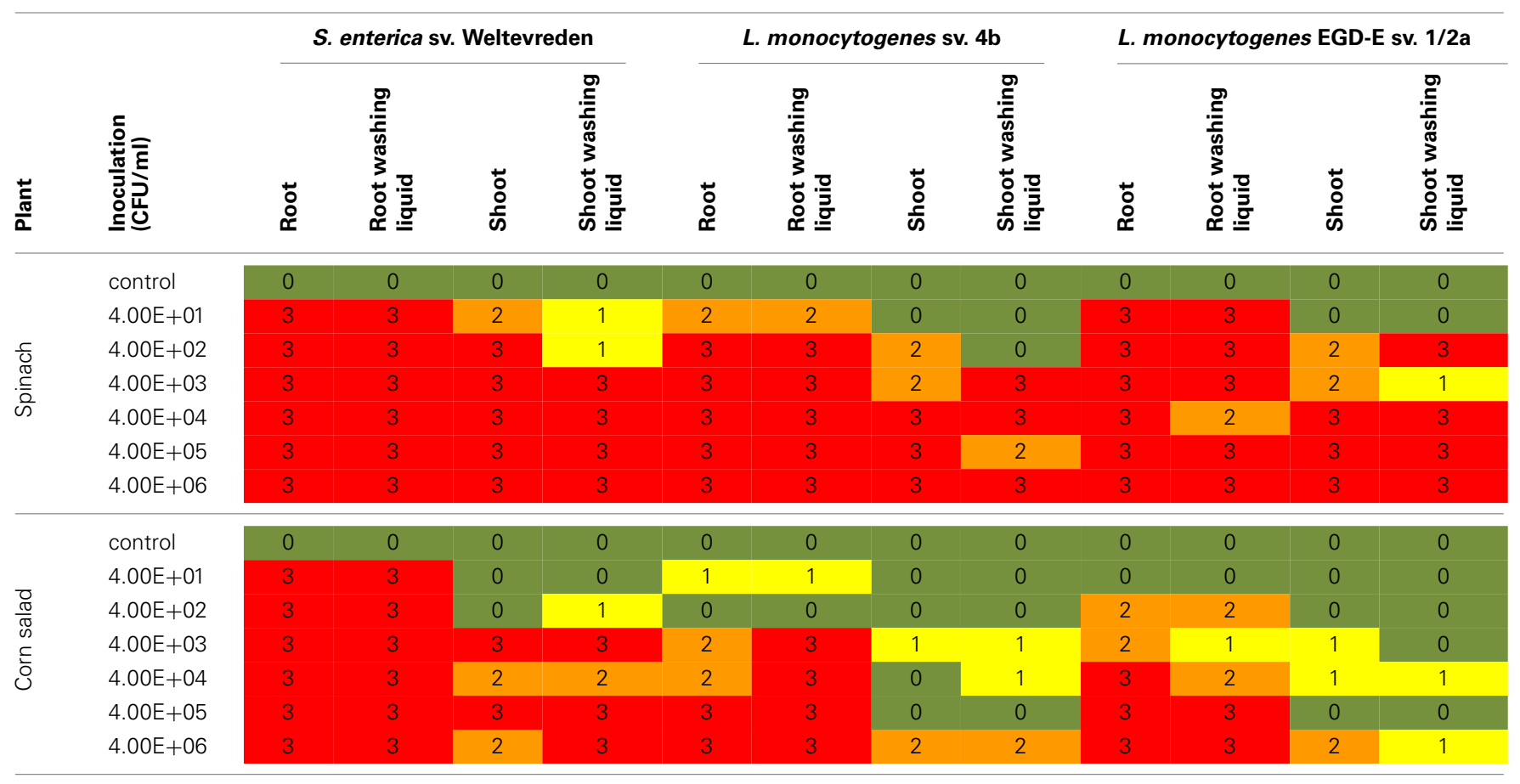

Numbers and colors in the table indicate the numbers of positive detections of the bacterial strains of interest with at least one of the applied detection methods. For each dilution step three plants were analyzed. 
$4 \times 10^{6} \mathrm{CFU} / \mathrm{ml}$. The same was true for corn salad inoculated with L. monocytogenes EGD-E sv. 1/2a, with the exception that root colonization took already place at an inoculation dose of $4 \times 10^{2} \mathrm{CFU} / \mathrm{ml}$.

\section{Combined FISH/CLSM analysis of inoculated roots}

In order to localize the inoculated bacteria on the roots of spinach and corn salad and to identify preferential colonization sites, a combined FISH/CLSM analysis was conducted. Salmonella enterica sv. Weltevreden was found to colonize spinach roots preferentially in the root hair zone. It was detected both, on the surface of the root hairs (Figure 1) as well as in cell interspaces of the main root in this zone (Figure 2). On corn salad roots the bacteria were

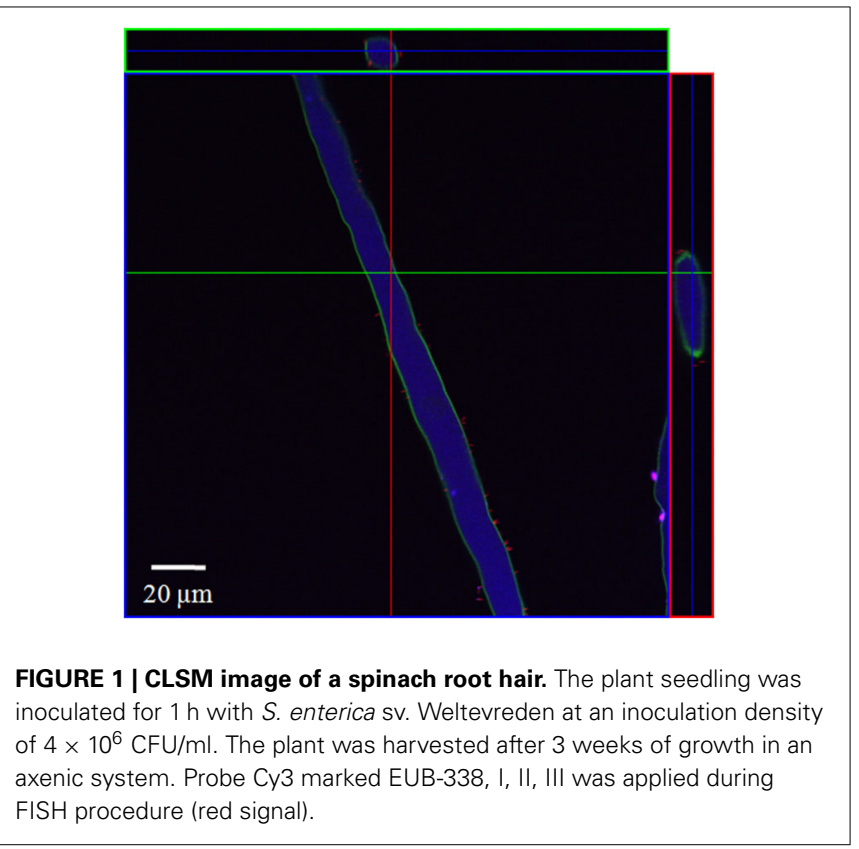

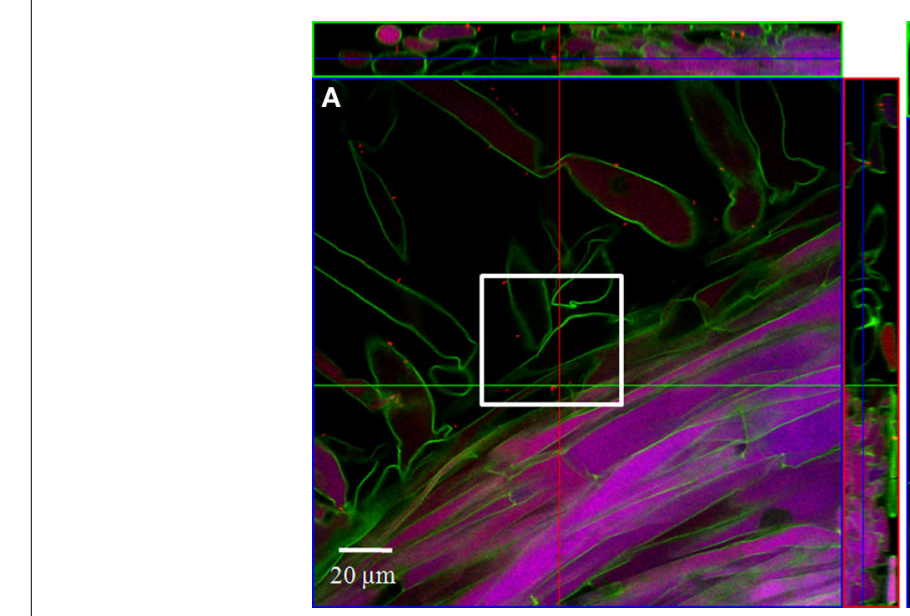

FIGURE 2 | CLSM images of a spinach root. The plant seedling was inoculated for $1 \mathrm{~h}$ with $S$. enterica sv. Weltevreden at an inoculation

density of $4 \times 10^{6} \mathrm{CFU} / \mathrm{ml}$. The plant was harvested after 3 weeks of mainly detected on the surface of root tip cells (Figure 3A) and rarely in the root hair zone (data not shown). On the root tip even a colonization of the glycocalix was observed (Figure 3B). Listeria monocytogenes sv. $4 \mathrm{~b}$ colonized spinach roots in the root hair zone in cell interspaces of the root (Figure 4). It was not detected on root hairs or on the root tips (data not shown). Corn salad plants were mainly colonized by L. monocytogenes sv. $4 \mathrm{~b}$ shortly behind the root tip but were not detected at the root tip (Figure 5). They were also found in cell interspaces of older root parts, but only in rare cases and small numbers (Figure 5).

\section{SPIKING EXPERIMENTS IN THE SOIL SYSTEM}

The detection of S. enterica sv. Weltevreden was performed using invA gene specific PCR after enrichment in BPW, whereas colonization by the L. monocytogenes strains was analyzed using the iap gen targeted PCR as well as a selective enrichment. All obtained PCR-fragments were sequenced to avoid false positive results. In the samples qualified as "positive" at least one of the used methods of analysis was successful. The results are summarized in Table 2.

\section{Colonization by S. enterica sv. Weltevreden}

Spinach roots were colonized by S. enterica sv. Weltevreden at all investigated spiking densities independent from the organic fertilizer used. Shoot plant samples of spinach were exclusively tested "positive" when fertilized with spiked slurry even at the lowest spiking density of $4 \times 10^{5} \mathrm{CFU} / \mathrm{ml}$. In contrast, in shoot washing liquid samples the bacteria were only detected at high spiking doses of at least $4 \times 10^{7} \mathrm{CFU} / \mathrm{ml}$, independent of the organic fertilizer used.

Corn salad roots were found to be colonized by the tested bacteria in samples of all spiking doses. More frequent positive detection events were observed in root washing liquid samples compared to the root samples. Salmonella enterica sv. Weltevreden was detected in three shoot samples fertilized with spiked slurry at spiking densities of $4 \times 10^{6}$ and $4 \times 10^{7} \mathrm{CFU} / \mathrm{ml}$

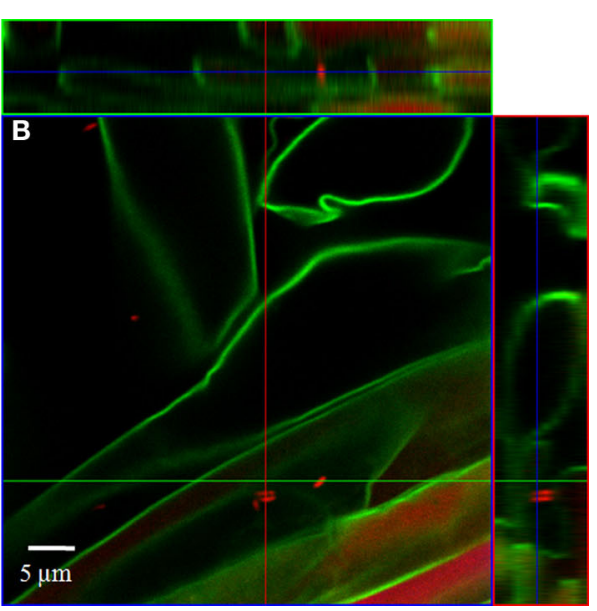

growth in an axenic system. Probe Cy3 marked 338, I, II, III was applied during FISH procedure (red signal). (B) is an enlarged capture of the area marked in (A). 


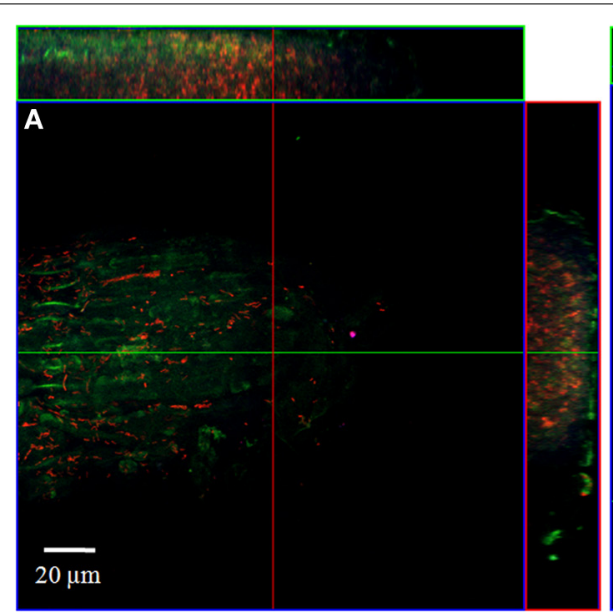

FIGURE 3 | CLSM images of corn salad root tips. The plant seedlings were inoculated for $1 \mathrm{~h}$ with $S$. enterica sv. Weltevreden at an inoculation density of $4 \times 10^{6} \mathrm{CFU} / \mathrm{ml}$. The plants were harvested after 3 weeks of growth in an

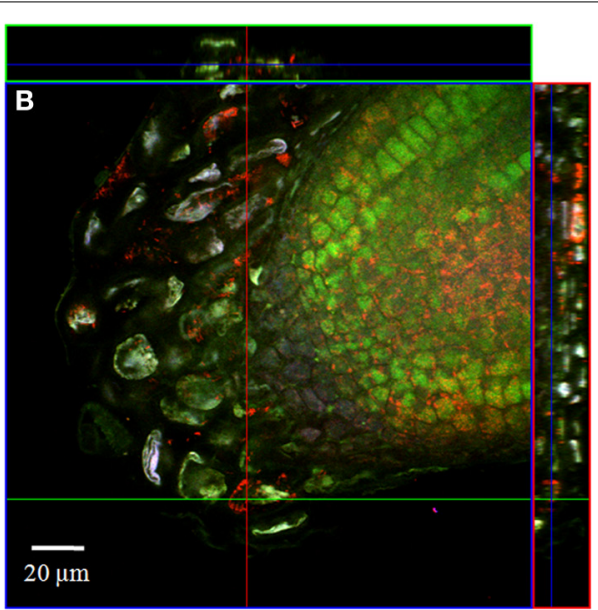

axenic system. Probe Cy3 marked EUB-338, I, II, III was applied during FISH procedures (red signal). The images show (A) surface colonization and (B) glycocalix colonization of the root tips.

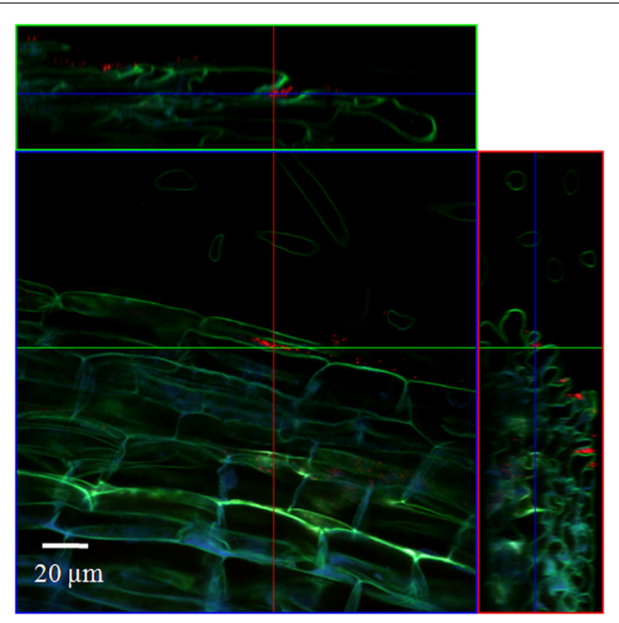

FIGURE 4 | CLSM image of a spinach root. The plant seedling was inoculated for $1 \mathrm{~h}$ with $\mathrm{L}$. monocytogenes sv. $4 \mathrm{~b}$ at an inoculation density of $4 \times 10^{6} \mathrm{CFU} / \mathrm{ml}$. The plant was harvested after 3 weeks of growth in an axenic system. Probe Cy3 marked EUB-338, I, II, III was applied during FISH procedure (red signal).

whereas only one washing liquid sample at a spiking density of $4 \times 10^{7} \mathrm{CFU} / \mathrm{ml}$ was found to be positive. Corn salad shoots of plants fertilized with spiked manure were exclusively colonized by the bacteria of interest at the highest spiking dose of $4 \times 10^{8}$ $\mathrm{CFU} / \mathrm{ml}$. Washing liquid samples also here were more often tested positive compared to plant samples.

\section{Colonization by the L. monocytogenes serovariations}

No bacterial colonization was found in plants when L. monocytogens sv. $4 \mathrm{~b}$ spiked slurry was used and for corn salad amended with L. monocytogenes EGD-E sv. 1/2a spiked organic fertilizer. In spinach samples, fertilized with $L$. monocytogenes sv. $4 \mathrm{~b}$ spiked manure, the bacteria of interest were only detected in root and root washing samples of the two highest spiking doses. For corn salad fertilized with spiked manure, only few samples independent of the spiking doses were tested positive. In this treatment even a contamination of a control plant was observed, which might be due to the fact that a contamination of soil or manure with L. monocytogenes cannot be excluded as those bacteria are very commonly found in this environments. Spinach fertilized with L. monocytogenes EGD-E sv. 1/2a spiked organic fertilizer was also only very rarely colonized.

\section{DISCUSSION}

The experiments presented in this study were conducted to identify the minimal infection doses of S. enterica sv. Weltevreden, L. monocytogenes sv. $4 \mathrm{~b}$, and L. monocytogenes EGD-E sv. 1/2 a needed for colonization of spinach or corn salad plants at axenic or at soil conditions. In order to achieve the highest sensitivity for the detection of a pathogen contamination, an enrichment step was used before DNA extraction and PCR analysis were performed. However, due to this enrichment step no complete quantitative analysis of the contamination was possible. In a similar experimental approach Arthurson et al. (2011) stated that the detection limit for S. enterica sv. Weltevreden is approximately $10^{4}$ CFU/g soil or plant material when quantitative PCR is applied. The same detection limit was reached for L. monocytogenes by Chen et al. (2011) when using direct PCR detection with different food matrices. In contrast, the authors were able to lower the detection limit down to $3 \mathrm{CFU} / \mathrm{ml}$ by introducing an enrichment step of $48 \mathrm{~h}$ in BLEB. Danyluk and Schaffner (2011) stated that on spinach plants E. coli O157:H7 cell numbers of $10^{-1} \mathrm{CFU} / \mathrm{g}$ on $0.1 \%$ of the plants at the time point of harvest are enough to possibly cause an outbreak. This assumption was made using a model, based on data, which revealed a strong growth of contaminant bacteria on harvested plant material if no cooling was applied (Abdul-Raouf et al., 1993; Chang and Fang, 2007; Lee and Baek, 2008). This demonstrated the need of a method with an extremely low detection limit, when analyzing human pathogenic bacteria on plants. 

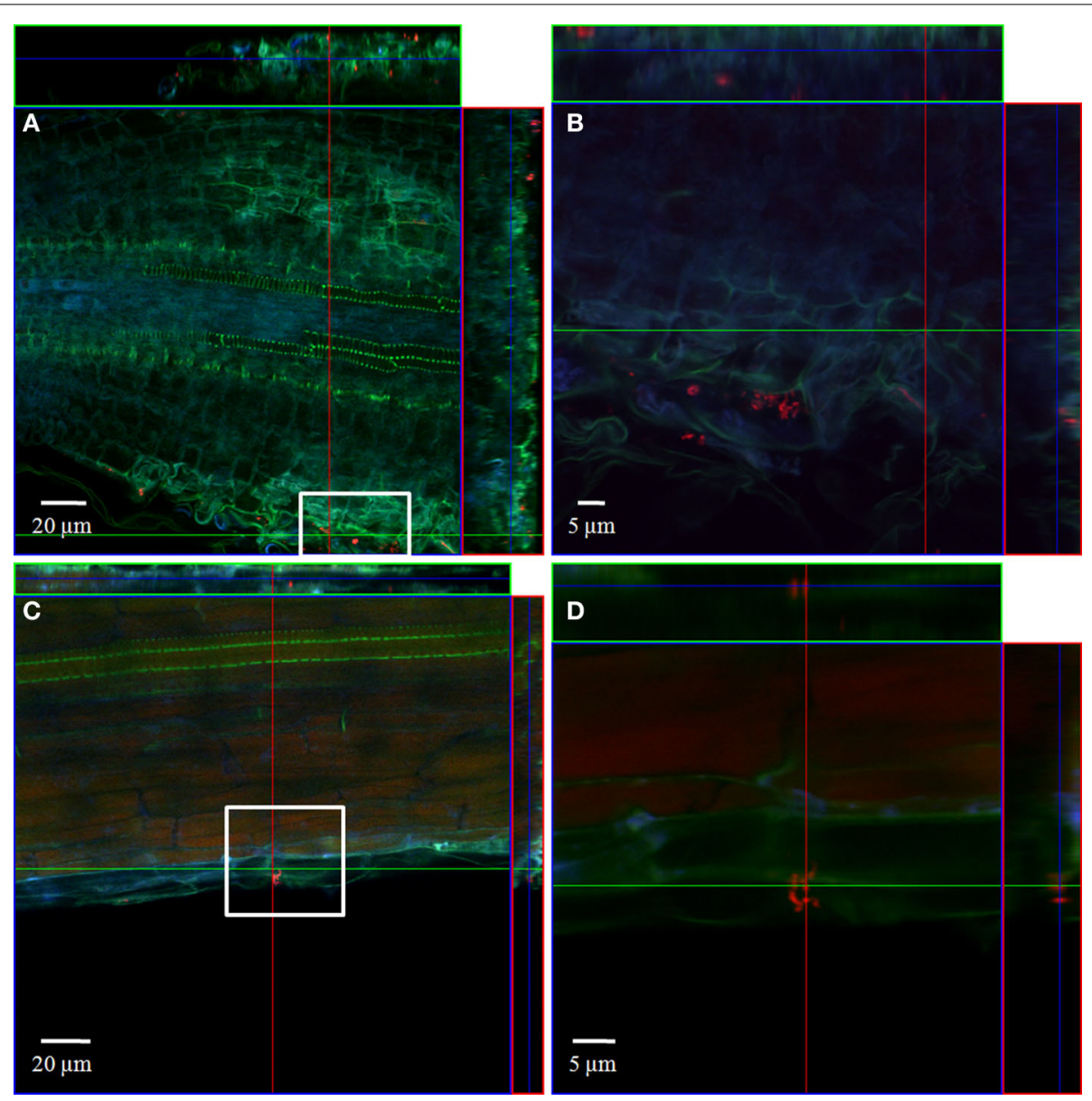

FIGURE 5 | CLSM images of a corn salad root tip (A,B) and a corn salad main root (C,D). The plant seedlings were inoculated for $1 \mathrm{~h}$ with $L$. monocytogenes sv. $4 \mathrm{~b}$ at an inoculation density of $4 \times 10^{6} \mathrm{CFU} / \mathrm{ml}$. The plants were harvested after 3 weeks of growth in an axenic system. Probe Cy3 marked EUB-338, I, II, III was applied during FISH procedure (red signal). (B) is an enlarged capture of the area marked in (A), (D) is an enlarged capture of the area marked in (C).
In addition to the highly sensitive detection, we also intended to localize the inoculated or spiked pathogens using fluorescence labeling of the bacteria by FISH and CLSM-analysis. Earlier studies have already shown that $S$. enterica can form biofilms on leaf surfaces (Kroupitski et al., 2009b) and even colonize the leaf interior via open stomata (Kroupitski et al., 2009a), which supports our findings in the axenic inoculation experiments. Especially in spinach, S. enterica sv. Wletevreden and L. monocytogenes sv. $4 \mathrm{~b}$ were often detected in shoot samples, but could not be washed off. Although, it was not possible with FISH/CLSM combined analyses of plant shoot material to clearly identify bacterial cells (data not shown) due to the strong auto-fluorescent properties of the plant material (Amann et al., 1990; Cheng et al., 2001; Ongeng et al., 2013), a strong colonization of spinach shoots could be demonstrated with the PCR-technique. In contrast, in all our experiments using corn salad or L. monocytogenes EGDE sv. 1/2a as inoculant, the bacteria were detected more often in washing liquid samples compared to the plant samples. In those cases it was even possible to remove the bacteria completely by the simple washing step. FISH/CLSM combined analysis of the root samples from the axenic system nevertheless revealed differential colonization sites depending on bacterial species as well as on plant species used for inoculation. Although no endophytic colonization which was observed for S. enterica and E. coli by Jablasone et al. (2005) was detected, the presence of the bacteria in cell interspaces of the root surface show a quite strong and persistent colonization of the plant roots.

The species or serovar of human pathogenic bacteria used for inoculation or spiking has a major influence on the extend of plant colonization. Salmonella enterica sv. Weltevreden was able to colonize the plants more efficiently and at lower initial inoculation or spiking dose compared to both serovariations of Listeria monocytogenes. This may be due to the fact that the strain used in this study was originally isolated from an outbreak traced back to the consumption of alfalfa sprouts (Emberland et al., 2007) and therefore was well adapted to colonize plants, in contrast to L. monocytogenes sv. 1/2a EGD-E which was isolated from rabbits (Murray et al., 1926) and L. monocytogenes sv. 4b isolated from a listeriosis patient (according to the Special Listeria Culture Collection, SLCC). Furthermore, it is known that $S$. enterica can be transferred to plants via contaminated organic fertilizer and soil (Klerks et al., 2007; Arthurson et al., 2011; Barak et al., 2011). 
Table 2 | Results of the spiking experiments in the soil system.

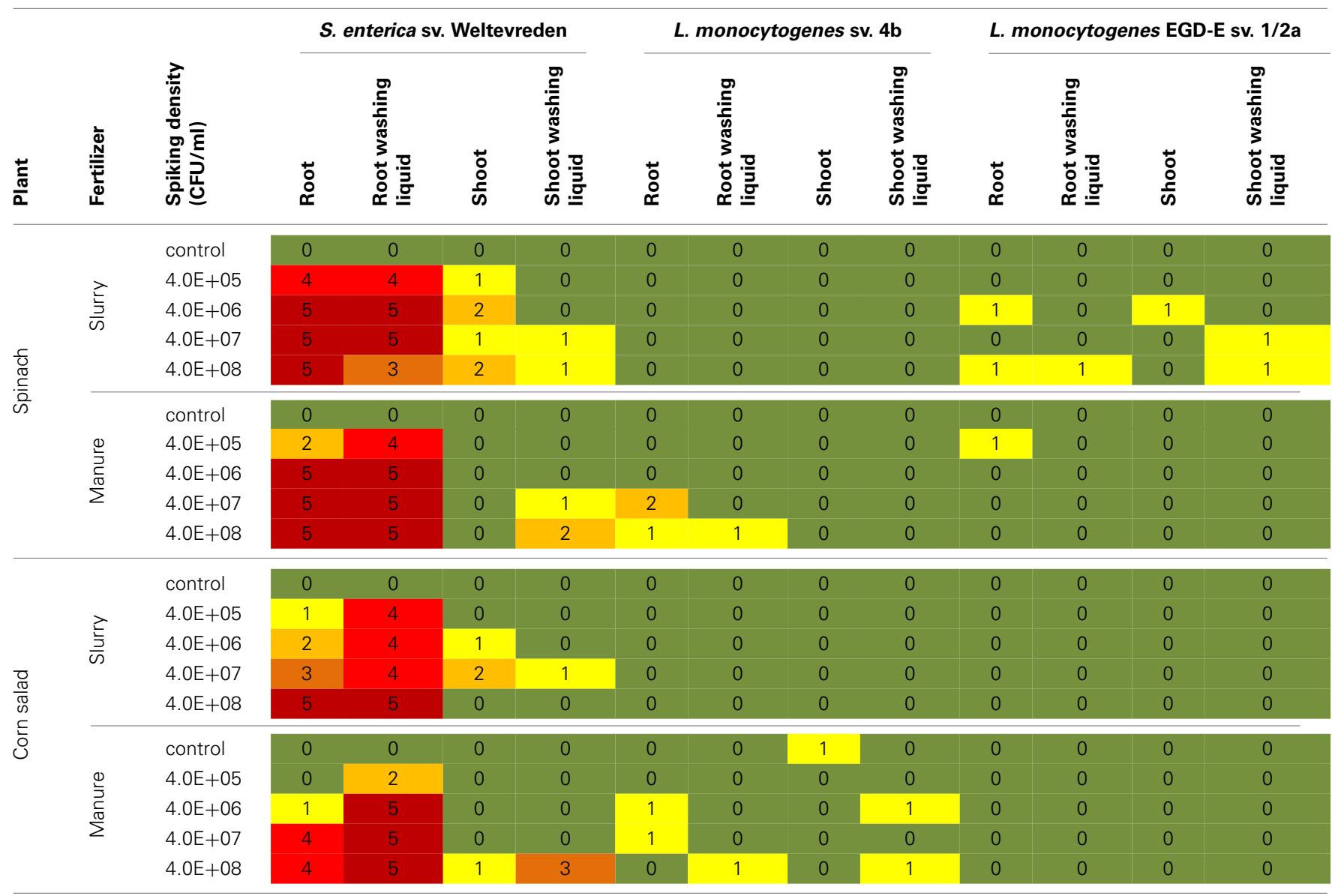

Numbers and colors indicate the number of positive detection events. For each dilution step five plants were analyzed.

In studies proving an endophytic colonization potential of $S$. enterica, L. monocytogenes was, in contrast, only detected on the plant surface (Jablasone et al., 2005; Kutter et al., 2006). Although being able to survive in soil (Botzler et al., 1974; Gorski et al., 2011) or manure amended soil (Jiang et al., 2004), L. monocytogenes was found to be inhibited by resident soil microbiota which can lead to a reduction of the cell numbers (McLaughlin et al., 2011). All this support our findings, that L. monocytogenes was only in few cases able to colonize plants in the soil system whereas colonization of plants grown in the axenic system was observed at even very low inoculation doses. Although differences in colonization success and interaction of some Salmonella spp. strains with lettuce cultivars have already been identified (Franz et al., 2007; Klerks et al., 2007), more research on the mechanisms of plant contamination by human pathogenic bacteria, including a higher number of bacterial strains is needed to clearly identify the reasons for the observed differences in the colonization success.

Furthermore, the plant species plays a crucial role in the colonization success by human pathogenic bacteria. Salmonella enterica and both L. monocytogenes serovariations were detected more frequently and at lower initial inoculation dose in spinach samples grown in the axenic system compared to corn salad plants.
The same was true for the spiking experiments with S. enterica. Literature supports those findings. Yadav et al. (2005) for example showed that bacterial colonization of leaf surfaces strongly depends on the properties of those leaves, like water and phosphorus content or leafs and mesophyll thickness. Zhang et al. (2010) detected significantly different bacterial communities on leafs of different vegetable plant species. Even a plant cultivar based effect on the colonization of lettuce by $S$. enterica was proven by Klerks et al. (2007).

The type of organic fertilizer used also influences the colonization of the plants by the human pathogenic bacteria used. Salmonella enterica was detected more often and at lower spiking doses if the plants were grown in slurry amended soil. The reduction or removal of the plant contamination with simple washing of the vegetables was also less successful in those samples. Hutchison et al. (2004) found a direct influence of humidity and severity of pathogen contamination in a large sampling campaign of organic fertilizers. The higher humidity of the slurry compared to manure might therefore enhance survival of the pathogenic bacteria first in the organic fertilizer and later in soil. This is supported by findings of Semenov et al. (2009) showing that $S$. enterica as well as E. coli display an enhanced survival rate in slurry amended soil compared to manure amended soil due to 
the higher content of dissolved organic nitrogen and carbon in the slurry.

\section{CONCLUSIONS}

De Roever (1998) formulated research needs to improve safety of fresh produce for the consumer. One of the key issues, which were also addressed in our study, is to improve farming practice in order to decrease the potential for produce contamination. We were able to show that this potential is strongly depending on the plant species under consideration. Therefore, "high risk plants," in our case spinach, need to be treated with more care during production, harvest and processing. Furthermore, the type of organic fertilizer used also influences the colonization success. In order to minimize the risk of transfer of human pathogenic bacteria to produce, manure instead of slurry should preferably be used. Fermentation or composting increased the safety of the fertilizer by minimizing the number of pathogenic bacteria present (Vinnerås, 2007; Abdel-Mohsein et al., 2010). Plant roots were usually colonized more frequently compared to shoots. Therefore, co-harvesting of roots should be avoided as much as possible. Although the pathogenic bacteria were shown to colonize the plant surface, the possibility of an endophytic colonization, especially for S. enterica sv. Weltevreden cannot be excluded. We demonstrated that washing was suitable to reduce or even remove the bacterial contamination in most cases. Since the bacteria were frequently detectable in the washing liquid, it should not be reused. Washing of vegetable plants is therefore useful but should be performed under flowing water. By this simple means, the risk of contamination of produce with human pathogenic bacteria can already be reduced on farming level, which increases safety for the final consumer.

\section{ACKNOWLEDGMENTS}

This study was financed by the EU project PATHORGANIC (Risks and Recommendations Regarding Human Pathogens in Organic Vegetable Production Chains) in the frame of CORE Organic (Core Organic 2006-1888, project number 07OE002).

\section{REFERENCES}

Abdel-Mohsein, H., Yamamoto, N., Otawa, K., Tada, C., and Nakai, Y. (2010). Isolation of bacteriocin-like substances producing bacteria from finished cattle-manure compost and activity evaluation against some food-borne pathogenic and spoilage bacteria. J. Gen. Appl. Microbiol. 56, 151-161. doi: 10.2323/jgam. 56.151

Abdul-Raouf, U. M., Beuchat, L. R., and Ammar, M. S. (1993). Survival and growth of Escherichia coli O157: H7 on salad vegetables. Appl. Environ. Microbiol. 59, 1999-2003.

Amann, R. I., Krumholz, L., and Stahl, D. A. (1990). Fluorescent-oligonucleotide probing of whole cells for determinative, phylogenetic, and environmental studies in microbiology. J. Bacteriol. 172, 762-770.

Amann, R. I., Zarda, B., Stahl, D. A., and Schleifer, K. H. (1992). Identification of individual prokaryotic cells by using enzyme-labeled, rRNA-targeted oligonucleotide probes. Appl. Environ. Microbiol. 58, 3007-3011.

Arthurson, V., Sessitsch, A., and Jäderlund, L. (2011). Persistence and spread of Salmonella enterica serovar Weltevreden in soil and on spinach plants. FEMS Microbiol. Lett. 314, 67-74. doi: 10.1111/j.1574-6968.2010. 02140.x

Barak, J. D., Kramer, L. C., and Hao, L. (2011). Colonization of tomato plants by Salmonella enterica is cultivar dependent, and type 1 trichomes are preferred colonization sites. Appl. Environ. Microbiol. 77, 498-504. doi: 10.1128/AEM.01661-10
Berger, C. N., Sodha, S. V., Shaw, R. K., Griffin, P. M., Pink, D., Hand, P., et al. (2010). Fresh fruit and vegetables as vehicles for the transmission of human pathogens. Environ. Microbiol. 12, 2385-2397. doi: 10.1111/j.14622920.2010.02297.x

Blanck, H. M., Gillespie, C., Kimmons, J. E., Seymour, J. D., and Serdula, M. K. (2008). Trends in fruit and vegetable consumption among U.S. men and women, 1994-2005. Prev. Chronic Dis. 5, 1-9. Available online at: http://www. cdc.gov/pcd/issues/2008/apr/07_0049.htm

Botzler, R., Cowan, A., and Wetzler, T. (1974). Survival of Listeria monocytogenes in soil and water. J. Wildlife 10, 204-212. doi: 10.7589/0090-3558-10.3.204

Brandl, M. T. (2006). Fitness of human enteric pathogens on plants and implications for food safety. Annu. Rev. Phytopathol. 44, 367-392. doi: 10.1146/annurev.phyto.44.070505.143359

Bubert, A., Köhler, S., and Goebel, W. (1992). The homologous and heterologous regions within the iap gene allow genus- and species-specific identification of Listeria spp. by polymerase chain reaction. Appl. Environ. Microbiol. 58, 2625-2632.

Center of Disease Control and Prevention. (2010). Morbidity and Mortality Weekly Report Surveillance For Foodborne Disease Outbreaks-United States, 2007. Atlanta, GA.

Center of Disease Control and Prevention. (2011). Multistate Outbreak of Listeriosis Associated with Jensen Farms Cantaloupe-United States, 2011. Atlanta, GA.

Chang, J.-M., and Fang, T. J. (2007). Survival of Escherichia coli O157:H7 and Salmonella enterica serovars Typhimurium in iceberg lettuce and the antimicrobial effect of rice vinegar against E. coli O157:H7. Food Microbiol. 24, 745-751. doi: 10.1016/j.fm.2007.03.005

Chen, Y., Kumar, N., and Siddique, N. (2011). Development and evaluation of a real-time polymerase chain reaction assay targeting iap for the detection of Listeria monocytogenes in select food matrices. Foodborne Pathog. Dis. 8, 1063-1069. doi: 10.1089/fpd.2010.0820

Chen, Z., and Jiang, X. (2014). Microbiological safety of chicken litter or chicken litter-based organic fertilizers: a review. Agriculture 4, 1-29. doi: 10.3390/agriculture 4010001

Cheng, P., Lin, B., Kao, F., Gu, M., Xu, M., Gan, X., et al. (2001). Multi-photon fluorescence microscopy-the response of plant cells to high intensity illumination. Micron 32, 661-669. doi: 10.1016/S0968-4328(00)00068-8

Daims, H., Brühl, A., Amann, R., Schleifer, K. H., and Wagner, M. (1999). The domain-specific probe EUB338 is insufficient for the detection of all Bacteria: development and evaluation of a more comprehensive probe set. Syst. Appl. Microbiol. 22, 434-444. doi: 10.1016/S0723-2020(99)80053-8

Danyluk, M. D., and Schaffner, D. W. (2011). Quantitative assessment of the microbial risk of leafy greens from farm to consumption: preliminary framework, data, and risk estimates. J. Food Protect. 74, 700-708. doi: 10.4315/0362028X.JFP-10-373

De Roever, C. (1998). Microbiological safety evaluations and recommendations on fresh produce. Food Control 9, 321-347. doi: 10.1016/S0956-7135(98)00022-X

Don, R. H., Cox, P. T., Wainwright, B. J., Baker, K., and Mattick, J. S. (1991). Touchdown PCR to circumvent spurious priming during gene amplification. Nucleic Acids Res. 19, 4008. doi: 10.1093/nar/19.14.4008

Emberland, K., Ethelberg, S., Kuusi, M., Vold, L., Jensvoll, L., Lindstedt, B., et al. (2007). Outbreak of salmonella weltevreden infections in Norway, Denmark and Finland associated with alfalfa sprouts, July-October 2007. Euro Surveill. 12, 1-4. Available online at: http://www.eurosurveillance.org/ViewArticle.aspx? ArticleId $=3321$

Farber, J., and Peterkin, P. (1991). Listeria monocytogenes, a food-borne pathogen. Microbiol. Rev. 55, 476-511.

Fliss, I., Emond, E., Simard, R. E., and Pandian, S. (1991). A rapid and efficient method of lysis of Listeria and other gram-positive bacteria using mutanolysin. Biotechniques 11, 453, 456-457.

Franz, E., Visser, A. A., Van Diepeningen, A. D., Klerks, M. M., Termorshuizen, A. J., and Van Bruggen, A. H. C. (2007). Quantification of contamination of lettuce by GFP-expressing Escherichia coli O157:H7 and Salmonella enterica serovar Typhimurium. Food Microbiol. 24, 106-112. doi: 10.1016/j.fm.2006.03.002

Gorski, L., Duhé, J. M., and Flaherty, D. (2011). The Sigma B operon is a determinant of fitness for a Listeria monocytogenes serotype $4 \mathrm{~b}$ strain in soil. Foodborne Pathog. Dis. 8, 699-704. doi: 10.1089/fpd.2010.0752

Grube, M., Cardinale, M., De Castro, J. V., Müller, H., and Berg, G. (2009). Speciesspecific structural and functional diversity of bacterial communities in lichen symbioses. ISME J. 3, 1105-1115. doi: 10.1038/ismej.2009.63 
Handeland, K., Refsum, T., Johansen, B. S., Holstad, G., Knutsen, G., Solberg, I., et al. (2002). Prevalence of salmonella typhimurium infection in Norwegian hedgehog populations associated with two human disease outbreaks. Epidemiol. Infect. 128, 523-527. doi: 10.1017/S09502688 02007021

Hanning, I. B., Nutt, J. D., and Ricke, S. C. (2009). Salmonellosis outbreaks in the United States due to fresh produce: sources and potential intervention measures. Foodborne Pathog. Dis. 6, 635-648. doi: 10.1089/fpd.2008.0232

Heaton, J. C., and Jones, K. (2008). Microbial contamination of fruit and vegetables and the behaviour of enteropathogens in the phyllosphere: a review. J. Appl. Microbiol. 104, 613-626. doi: 10.1111/j.1365-2672.2007.03587.x

Hellström, S., Kiviniemi, K., Autio, T., and Korkeala, H. (2008). Listeria monocytogenes is common in wild birds in Helsinki region and genotypes are frequently similar with those found along the food chain. J. Appl. Microbiol. 104, 883-888. doi: 10.1111/j.1365-2672.2007.03604.x

Hutchison, M., Walters, L., Avery, S., Munro, F., and Moore, A. (2005). Analyses of livestock production, waste storage, and pathogen levels and prevalences in farm manures. Appl. Environ. Microbiol. 71, 1231-1236. doi: 10.1128/AEM.71. 3.1231

Hutchison, M., Walters, L., Avery, S., Synge, B., and Moore, A. (2004). Levels of zoonotic agents in British livestock manures. Lett. Appl. Microbiol. 39, 207-214. doi: 10.1111/j.1472-765X.2004.01564.x

Jablasone, J., Warriner, K., and Griffiths, M. (2005). Interactions of Escherichia coli O157:H7, Salmonella typhimurium and Listeria monocytogenes plants cultivated in a gnotobiotic system. Int. J. Food Microbiol. 99, 7-18. doi: 10.1016/j.ijfoodmicro.2004.06.011

Jiang, X., Islam, M., Morgan, J., and Doyle, M. P. (2004). Fate of Listeria monocytogenes in bovine manure-amended soil. J. Food Prot. 67, 1676-1681. Available online at: http://www.ingentaconnect.com/content/iafp/jfp/2004/00000067/ 00000008/art00018?token $=005012$ ec145a666f3a7b6c2a40636f316b41523e6b25 49264f65263a3d4f58762f46a3dlaca5225f

Klerks, M. M., Franz, E., Van Gent-Pelzer, M., Zijlstra, C., and Van Bruggen, A. H. C. (2007). Differential interaction of Salmonella enterica serovars with lettuce cultivars and plant-microbe factors influencing the colonization efficiency. ISME J. 1, 620-631. doi: 10.1038/ismej.2007.82

Kroupitski, Y., Golberg, D., Belausov, E., Pinto, R., Swartzberg, D., Granot, D., et al. (2009a). Internalization of Salmonella enterica in leaves is induced by light and involves chemotaxis and penetration through open stomata. Appl. Environ. Microbiol. 75, 6076-6086. doi: 10.1128/AEM.01084-09

Kroupitski, Y., Pinto, R., Brandl, M. T., Belausov, E., and Sela, S. (2009b). Interactions of Salmonella enterica with lettuce leaves. J. Appl. Microbiol. 106, 1876-1885. doi: 10.1111/j.1365-2672.2009.04152.x

Krtinić, G., Đurić, P., and Ilić, S. (2010). Salmonellae in food stuffs of plant origin and their implications on human health. Eur. J. Clin. Microbiol. Infect. Dis. 29, 1321-1325. doi: 10.1007/s10096-010-1001-4

Kutter, S., Hartmann, A., and Schmid, M. (2006). Colonization of barley (Hordeum vulgare) with Salmonella enterica and Listeria spp. FEMS Microbiol. Ecol. 56, 262-271. doi: 10.1111/j.1574-6941.2005.00053.x

Lee, S.-Y., and Baek, S.-Y. (2008). Effect of chemical sanitizer combined with modified atmosphere packaging on inhibiting Escherichia coli O157:H7 in commercial spinach. Food Microbiol. 25, 582-587. doi: 10.1016/j.fm.2008. 02.003

Lettini, A. A., Barco, L., Mancin, M., Ramon, E., Longo, A., Pozza, M. C. D., et al. (2012). A pilot study for identification of Salmonella in food processing plants by real-time PCR screening. Food Anal. Methods 5, 988-994. doi: 10.1007/ s12161-011-9352-8

Makino, S., Kobori, H., Asakura, H., Watarai, M., Shirahata, T., Ikeda, T., et al. (2000). Detection and characterization of Shiga toxin-producing Escherichia coli from seagulls. Epidemiol. Infect. 125, 55-61. doi: 10.1017/S0950268899004100

Manz, W., Amann, R., Ludwig, W., Wagner, M., and Schleifer, K. H. (1992). Phylogenetic oligodeoxynucleotide probes for the major subclasses of proteobacteria: problems and solutions. Syst. Appl. Microbiol. 15, 593-600. doi: 10.1016/S0723-2020(11)80121-9

McLaughlin, H. P., Casey, P. G., Cotter, J., Gahan, C. G. M., and Hill, C. (2011). Factors affecting survival of Listeria monocytogenes and Listeria innocua in soil samples. Arch. Microbiol. 193, 775-785. doi: 10.1007/s00203-0110716-7

McLauchlin, J. (1996). The relationship between Listeria and listeriosis. Food Control 7, 187-193. doi: 10.1016/S0956-7135(96)00038-2
Millan, J., Aduriz, G., Moreno, B., Juste, R. A., and Barral, M. (2004). Salmonella isolates from wild birds and mammals in the Basque Country (Spain). Rev. Sci. Tech. 23, 905-911. Available online at: http://web.oie.int/boutique/index.php? page $=$ ficprod\&id_prec $=90 \&$ id_produit $=415 \&$ lang $=$ en\&fichrech $=1$

Murray, E. G. D., Webb, R. A., and Swann, M. B. R. (1926). A disease of Rabbits characterised by a large mononuclear Leucocytosis, caused by a hitherto undescribed bacillus Bacterium monocytogenes. J. Pathol. Bacteriol. 29, 407-439. doi: 10.1002/path.1700290409

O’Connor, L., O'Leary, M., Leonard, N., Godinho, M., O’Reilly, C., Coffey, L., et al. (2010). The characterization of Listeria spp. isolated from food products and the food-processing environment. Lett. Appl. Microbiol. 51, 490-498. doi: 10.1111/j.1472-765X.2010.02928.x

Ongeng, D., Geeraerd, A. H., Springael, D., Ryckeboer, J., Muyanja, C., and Mauriello, G. (2013). Fate of Escherichia coli O157:H7 and Salmonella enterica in the manure-amended soil-plant ecosystem of fresh vegetable crops: a review. Crit. Rev. Microbiol. 7828, 1-22. doi: 10.3109/1040841X.2013. 829415

Palmgren, H., Sellin, M., Bergström, S., and Olsen, B. (1997). Enteropathogenic bacteria in migrating birds arriving in Sweden. Scand. J. Infect. Dis. 29, 565-568. doi: 10.3109/00365549709035895

Rahn, K., De Grandis, S., Clarke, R. C., McEwen, S., Galán, J. E., Ginocchio, C., et al. (1992). Amplification of an invA gene sequence of Salmonella typhimurium by polymerase chain reaction as a specific method of detection of Salmonella. Mol. Cell. Probes 6, 271-279. doi: 10.1016/0890-8508(92)90002-F

Renter, D. G., Gnad, D. P., Sargeant, J. M., and Hygnstrom, S. E. (2006). Prevalence and serovars of Salmonella in the feces of free-ranging white-tailed deer (Odocoileus virginianus) in Nebraska. J. Wildlife Dis. 42, 699-703. doi: 10.7589/0090-3558-42.3.699

Roller, C., Wagner, M., Amann, R., and Ludwig, W. (1994). In situ probing of Gram-positive bacteria with high DNA G + C content using 23s rRNA- targeted oligonucleotides. Microbiology 140, 2849-2858. doi: 10.1099/00221287-14010-2849

Rothballer, M., Schmid, M., and Hartmann, A. (2003). In situ localization and PGPR-effect of Azospirillum brasilense strains colonizing roots of different wheat varieties. Symbiosis 34, 261-279. Available online at: http://www. bashanfoundation.org/hartmann/hartmannwheatvarieties.pdf

Sánchez, S., Martínez, R., García, A., Vidal, D., Blanco, J., Blanco, M., et al. (2010). Detection and characterisation of O157:H7 and non-O157 Shiga toxinproducing Escherichia coli in wild boars. Vet. Microbiol. 143, 420-423. doi: 10.1016/j.vetmic.2009.11.016

Sanger, F., Nicklen, S., and Coulson, A. R. (1977). DNA sequencing with chainterminating inhibitors. Proc. Natl. Acad. Sci. U.S.A. 74, 5463-5467. doi: 10.1073/pnas.74.12.5463

Semenov, A. V., Van Overbeek, L., and Van Bruggen, A. H. C. (2009). Percolation and survival of Escherichia coli O157:H7 and Salmonella enterica serovar Typhimurium in soil amended with contaminated dairy manure or slurry. Appl. Environ. Microbiol. 75, 3206-3215. doi: 10.1128/AEM.01 791-08

Sinde, E., and Carballo, J. (2000). Attachment of Salmonella spp. and Listeria monocytogenes to stainless steel, rubber and polytetrafluorethylene: the influence of free energy and the effect of commercial sanitizers. Food Microbiol. 17, 439-447. doi: $10.1006 /$ fmic. 2000.0339

Sivapalasingam, S., Friedman, C. R., Cohen, L., and Tauxe, R. V. (2004), Fresh produce: a growing cause of outbreaks of foodborne illness in the United States, 1973 through 1997. J. Food Prot. 67, 2342-2353. Available online at: http://www.ingentaconnect.com/content/iafp/jfp/2004/00000067/ $00000010 /$ art00041?token $=00491780 \mathrm{a} 164 \mathrm{ad} 57 \mathrm{~b} 76504 \mathrm{c} 486646255049446 \mathrm{c} 7 \mathrm{~b} 31$ $6359386 \mathrm{a} 332 \mathrm{~b} 25757 \mathrm{~d} 5 \mathrm{c} 4 \mathrm{f} 6 \mathrm{~d} 4 \mathrm{e} 227 \mathrm{a}$

United States Department of Agriculture. (2011). USDA and HHS Announce New Dietary Guidelines To Help Americans Make Healthier Food Choices And Confront Obesity Epidemic. Washington, DC: USDA Office of Communications and HHS Press Office.

US Food and Drug Administration. (2003). Quantitative Assessment Of Relative Risk To Public Health From Foodborne Listeria Monocytogenes Among Selected Categories Of Ready-To-Eat Foods. Silver Spring, MD: FDA/Center for Food Safety and Applied Nutrition.

Vieira-Pinto, M., Morais, L., Caleja, C., Themudo, P., Torres, C., Igrejas, G., et al. (2011). Salmonella sp. in game (Sus scrofa and Oryctolagus cuniculus). Foodborne Pathog. Dis. 8, 739-740. doi: 10.1089/fpd.2010.0742 
Vinnerås, B. (2007). Comparison of composting, storage and urea treatment for sanitising of faecal matter and manure. Bioresour. Technol. 98, 3317-3321. doi: 10.1016/j.biortech.2006.07.011

Wacheck, S., Fredriksson-Ahomaa, M., König, M., Stolle, A., and Stephan, R. (2010). Wild boars as an important reservoir for foodborne pathogens. Foodborne Pathog. Dis. 7, 307-312. doi: 10.1089/fpd. 2009.0367

Wachtel, M. R., Whitehand, L. C., and Mandrell, R. E. (2002). Association of Escherichia coli O157:H7 with preharvest leaf lettuce upon exposure to contaminated irrigation water. J. Food Prot. 65, 18-25. Available online at: http://www.ingentaconnect.com/content/iafp/jfp/2002/00000065/00000001/art 00003 ?token $=00511 \mathrm{fc} 040 \mathrm{e} 62 \mathrm{c} 577176 \mathrm{fec} 405847447 \mathrm{~b} 496 \mathrm{e} 2 \mathrm{f} 2 \mathrm{a} 31346 \mathrm{f} 386 \mathrm{~b} 35663$ 633757e6f4f2858592f3f3b57

World Health Organization. (2003). Fruit and Vegetable Promotion. Geneva: World Health Organization.

Yadav, R. K. P., Karamanoli, K., and Vokou, D. (2005). Bacterial colonization of the phyllosphere of mediterranean perennial species as influenced by leaf structural and chemical features. Microb. Ecol. 50, 185-196. doi: 10.1007/s00248-0040171-y

Zhang, B., Bai, Z., Hoefel, D., Wang, X., Zhang, L., and Li, Z. (2010). "Microbial diversity within the phyllosphere of different vegetable species," in Current
Research, Technology and Education Topics in Applied Microbiology and Microbial Biotechnology, ed A. Mendez-Vilas (Badajoz: Formatex Research Center), 1067-1077.

Conflict of Interest Statement: The authors declare that the research was conducted in the absence of any commercial or financial relationships that could be construed as a potential conflict of interest.

Received: 29 January 2014; paper pending published: 24 March 2014; accepted: 10 April 2014; published online: 05 May 2014.

Citation: Hofmann A, Fischer D, Hartmann A and Schmid M (2014) Colonization of plants by human pathogenic bacteria in the course of organic vegetable production. Front. Microbiol. 5:191. doi: 10.3389/fmicb.2014.00191

This article was submitted to Plant-Microbe Interaction, a section of the journal Frontiers in Microbiology.

Copyright (c) 2014 Hofmann, Fischer, Hartmann and Schmid. This is an openaccess article distributed under the terms of the Creative Commons Attribution License (CC BY). The use, distribution or reproduction in other forums is permitted, provided the original author(s) or licensor are credited and that the original publication in this journal is cited, in accordance with accepted academic practice. No use, distribution or reproduction is permitted which does not comply with these terms. 